\title{
Impact Assessment of the COVID-19 Outbreak on Indonesian Tourism
}

\author{
Ridwan Ridwan \\ Faculty of Economics and Business \\ Universitas Janabadra \\ Yogyakarta, Indonesia \\ ridwan@janabadra.ac.id \\ Alim Syariati \\ Faculty of Economics and Islamic \\ Business \\ Universitas Islam Negeri Alauddin \\ Makassar, Indonesia \\ alim.syariati@uin-alauddin.ac.id
}

\author{
Sarwoko Sarwoko \\ Faculty of Economics and Business \\ Universitas Janabadra \\ Yogyakarta, Indonesia \\ sarwoko@janabadra.ac.id \\ Sri Astuty \\ Faculty of Economics \\ Universitas Negeri Makassar \\ Makassar, Indonesia \\ sri.astuty@unm.ac.id
}

\author{
Danang Wahyudi \\ Faculty of Economics and Business \\ Universitas Janabadra \\ Yogyakarta, Indonesia \\ danang_wahyudi@janabadra.ac.id
}

\begin{abstract}
The global COVID-19 pandemic has brought the world to a standstill, and tourism has been the hardest hit from all major economic sectors. The United Nation World Tourism Organization (UNWTO) estimates that by 2020 the arrival of international tourists around the world could decrease drastically in all countries. Foreign tourist visits to Indonesia through all entrances in June 2020 decreased by $88.82 \%$ compared to June 2019. This study aims to estimate the impact of the COVID-19 pandemic on foreign tourist visits to Indonesia. In addition, to find out the impact of the COVID-19 pandemic on business actors supporting tourism in Indonesia and to what extent the policy response supports the Indonesian tourism sector during and after the COVID-19 pandemic. Hypothetical scenario analysis is used to estimate the decrease in the number of foreign tourists. Two scenarios are presented with relevant alternatives. The first scenario expects a decrease in foreign tourist visits at the same rate compared to the same month in the previous year. The second scenario is that the decline will be in the same proportion for each month after the restrictions on social activities are opened.
\end{abstract}

Keywords: COVID-19 pandemic, tourism, foreign tourists, estimation, scenario analysis

\section{INTRODUCTION}

The world is facing an unprecedented global health emergency. The global COVID-19 outbreak has brought the world to a standstill, and tourism has been hardest hit by all major economic sectors. The United Nation World Tourism Organization (UNWTO) estimates that by 2020 the arrival of international tourists around the world could decrease drastically in all countries. The COVID-19 outbreak has had an unmatched and unexpected impact on people's lives, economies and people's livelihoods to the growing risk of a global recession and the loss of many jobs.

The weakening of the tourism industry due to the corona virus has also occurred in Indonesia. Several tourist destinations, such as Bali, Yogyakarta and Lombok, experienced a drastic decrease in visitors. Foreign tourists visiting Indonesia through all entrances in February 2020 totaled 885,067 visits or decreased by $-28.85 \%$ compared to February 2019, which totaled 1,243,996 visits. Visits of foreign tourists at 3 (three) large doors of the 26 main entrances in February 2020 compared to February 2019, namely: Ngurah Rai decreased by $-17.88 \%$; Soekarno Hatta has decreased by $-33.21 \%$; and Batam has decreased by $40.18 \%$ [1].

Meanwhile, ASEAN member countries reported a decline in tourism performance of about 36 percent in the first quarter of 2020, compared to the same period in 2018 and 2019. International tourist arrival rates have decreased by around 34 percent, and hotel room occupancy rates are currently at lowest point and a lot of cancellations in the tour and travel industry [1].

At the time this research is being conducted, it is too early to estimate the full impact of COVID-19 on the tourism industry. For the initial assessment, for example, UNWTO took the 2003 SARS scenario as a benchmark, taking into account the size and dynamics of global travel and current disruptions, the geographic spread of COVID-19 and its potential economic impact. UNWTO underlines that any estimate must be treated with caution because of the unstable and uncertain evolution of the outbreak that could lead to uncertain changes in the future.

The SARS epidemic mainly attacked countries in Asia, namely China, Hong Kong, Singapore and Taiwan. The SARS epidemic is estimated to have cost these four countries a GDP loss of US \$ 20 billion, and a reduction of more than $70 \%$ across Asia, even in those countries no cases were detected [2]. Industry data show that international tourism to China, Hong Kong, Taiwan, and Vietnam fell 58 percent in the first quarter of 2003 [3]. After the SARS epidemic, Singapore's tourism gross domestic product (GDP) decreased by $43 \%$ and the number of tourism-related jobs lost was 17,500; Hong Kong's tourism GDP decreased by $41 \%$ and tourism-related job losses were 27,000; China's tourism GDP decreased by $25 \%$ and tourism-related job losses were 2.8 million, and Vietnam's tourism GDP fell by $15 \%$ and tourism-related job losses were 62,000 [4].

Furthermore, [5] reported that the extent of damage in Taiwan and China was less visible than in Hong Kong and Singapore, indicating that the government's reaction and strategies to deal with this serious disease could result in varying degrees of damage. For example, [6] asserted that 
the impact of SARS on Hong Kong's tourism industry was said to be more devastating than the events of 9 September or the 1997 Asian Financial crisis. In Singapore, visitor arrivals fell dramatically for the April 2003 to June 2003 quarters, reaching a rare figure, which is more from $70 \%$ lower than the previous year in May [7]. Also, Canada is another country infected with SARS with 251 cases and 41 deaths. In Canada, during the April 2004 to June 2004 quarter, international visitors fell 14\%, spending by international visitors fell $13 \%$, the international travel deficit rose to more than $\$ 1.1$ billion and tourism employment fell $2.4 \%[8]$.

Meanwhile, swine flu was first recorded in Mexico in March 2009 and then spread to the mottled areas of the Americas and then to further areas, especially Central and Eastern Europe, the Middle East and Southeast Asia [9]. Also [10] reported that Brunei lost nearly $15 \%$ of tourist demand from June 2009 to May 2010 (post swine flu). Furthermore, the swine flu pandemic had a significant negative effect on UK tourism demand in all tourist home countries, especially mainland China, Spain, South Korea and Russia, in the second quarter of 2009 [9].

Furthermore, the 2014 Ebola outbreak which started in Guinea in December 2013, spread to other West African countries, namely Sierra Leone and Liberia. During the Ebola outbreak, tourist arrivals across the African continent were reduced by $2 \%$ in 2014 , and a further $5 \%$ in October 2015, following the Ebola outbreak [11]. Meanwhile [12] mentioned about a $20 \%$ to $70 \%$ drop in bookings in 2014 as a result of the Ebola outbreak in Kenya.

Tourism is one of the most sensitive sectors to crises such as wars, terrorist attacks, natural disasters and other kinds of unwanted phenomena. Normally, tourism demand and forecasts could be done by some objective methods, but coronavirus pandemic has changed all the circumstances and affected all the conditions in the economic cycle.

At this point, forecasting tourist demand with subjective or hypothetical methods could be seen as a solution. This study aims to forecast the short-term effects of COVID-19 pandemic on foreign visitors' demand for Indonesia by using scenario analysis technique. The short-term effects of COVID-19 pandemic on foreign visitors' demand for Indonesia was analysed by using scenario analysis technique and some suggestions were made in the conclusion section. This study could be seen as an early prediction related to the effects of COVID-19 pandemic on tourist mobility to Indonesia. It has seen in the results that, decision-makers still have time to recover the effects of the pandemic in 2020.

\section{METHOD}

The data used in the study are secondary data on foreign tourist visits to Indonesia in the last three years. Data sources were obtained from the Statistics of Indonesia, the Ministry of Tourism and Creative Economy of the Republic of Indonesia (Kemenparekraf), the United Nation World Tourism Organization (UNWTO), The International Air Transport Association (IATA), and other sources from various media both offline and on line.

Scenario analysis is a technique used in economics, finance, or other fields to predict the future. In accounting, finance and economics, it is important to estimate the future for any investment decisions such as capital investment or portfolio selection. This technique is also used for risk management in finance [13]. In accounting, it is also used for the budgeting process to estimate costs and revenues [14]. This technique is widely studied in economics-based papers. Based on the information mentioned above, this study aims to make projections to see the impact of COVID19 on the number of foreign tourist visitors to Indonesia in 2020 within the scope of alternative scenarios. In this context, the researcher uses two hypothetical scenarios in which the rate of change in tourism demand is constant for each month or the decline will recover by the same proportion from the low level through December 2020. Each scenario has a set of alternatives that include border closure and each alternative is calculated for the rate a three base drop. This study only includes estimates of monthly Indonesian international tourist visits in 2020 compared to 2019 before the COVID-19 pandemic.

Hypothetical Scenarios. Two scenarios are presented with relevant alternatives. The first scenario expects a decrease in foreign tourist visits or at the same level compared to the same month in the previous year. In the second scenario, for each month after the opening of the border, demand will recover from the decline evenly. The second scenario is that the decline will be in the same proportion for each month after the border opens. This hypothetical scenario implies that demand will fall by a hypothetical percentage for the first month after the border is opened, and then will recover evenly.

Scenario A. The decrease in foreign tourist visits is at the same level for each month:

A1. There is no policy prohibiting foreigners from entering Indonesian territory;

A2. Enforcement of Large-Scale Social Restrictions (PSBB) for one month (April 2020);

A3. PSBB is enforced for two months (April - May 2020);

A4. The enforcement of PSBB for six months (April September 2020.

Scenario B. The decrease in foreign tourist visits will recover in the same proportion from month to month:

B1. There is no policy to prohibit foreigners from entering Indonesian territory;

B2. Enforcement of Large-Scale Social Restrictions (PSBB) for one month (April 2020);

B3. The enforcement of PSBB for two months (April May 2020);

B4. The enforcement of PSBB for six months (April September 2020).

UNWTO has announced expectations claiming that international tourist arrivals will fall by $20 \%$ to $30 \%$ for 2020 when compared to 2019 due to travel restrictions [15]. On the other hand, tourism actors hope that the COVID-19 pandemic will end soon [16]. Based on the expectations of the government and tourism actors, it is estimated that the projection of international tourist arrivals to Indonesia will be at a different level of decline. The number of monthly foreign tourist visits is calculated using Formula (1) as shown below [17].

Number of Foreign Visitors $\mathrm{tm}_{\mathrm{m}}=$ Number of Foreign Visitors $\mathrm{tm}_{\mathrm{tm}}-1 \times \mathrm{x}(1 \mp \mathrm{r})$

$t m$ is the calculated month, and $t m-1$ is the same month of the previous year. $r$ is the change rate. This calculation 
has been done for each forecasted month. Then the number of yearly arriving foreigners has been calculated as the sum of monthly data for 2020. Lastly, forecasted yearly data for 2020 was proportioned to 2019 as shown in formula (2) to put forth the rate of change percentage.

Estimated Rate of Change (\%) for Foreign Visitors $\mathrm{t}_{\mathrm{t}}=\frac{\text { Number of Foreign Visitors } \mathrm{t}_{\mathrm{t}}}{\text { Number of Foreign Visitors } \mathrm{t}_{\mathrm{t}-1}}-1$

\section{RESULTS AND DISCUSSION}

As shown in Table I, if the number of foreign tourist arrivals is assumed to decline by $30 \%$ constantly for each month from the rest of the year, it is estimated that the annual rate of change will be $-44 \%$ compared to 2019 due to the COVID-19 pandemic. On the other hand, if the effort to restore the demand for foreign tourist arrivals with the same proportion from month to month from the base rate, the rate of change would be $-33 \%$. If the level of monthly demand for foreign visits to be $80 \%$ compared to the previous year, as a constant decrease, the demand will decrease by $39 \%$. If there is a recovery from the baseline, the demand will decrease by $31 \%$. As can be seen in Table 1 , the number of tourists will decrease by $29 \%$ even if demand remains the same.

The findings of this study are not much different from the UNWTO, which estimates that international tourist arrivals can decrease by $20 \%$ to $30 \%$ in 2020 due to the COVID-19 pandemic. However, the facts show that foreign tourist arrivals to Indonesia have decreased since February, and even fell to $-64.10 \%$ in March compared to the same month in 2019. This indicates that the impact of the COVID-19 pandemic on Indonesian tourism has greatly exceeded UNWATO estimates. Therefore, the Indonesian Government then implemented a policy of prohibiting foreigners from entering Indonesian territory which took effect since early April 2020 [18].

Furthermore, the estimated number of foreign tourist arrivals and the annual rate of change are shown in Table II if the government imposes a policy of prohibiting foreigners from entering Indonesia for one month (until 30 April 2020) for two scenarios. As is known, to prevent the spread of COVID-19 in Indonesia, the Government has restricted travel for foreigners to Indonesian territory based on [18]

TABLE I. The estimated number of foreign visitors and annual change rate (what if borders are closed for a month)

\begin{tabular}{|c|c|c|c|c|c|c|c|c|}
\hline \multicolumn{5}{|c|}{ Scenario $\mathrm{A} 1^{\mathrm{b}}$} & \multicolumn{4}{|c|}{ Scenario $\mathrm{B} 1^{\mathrm{c}}$} \\
\hline \multicolumn{5}{|c|}{$\begin{array}{l}\text { Hypothetical monthly decline rate and } \\
\text { estimated numbers }\end{array}$} & \multicolumn{4}{|c|}{$\begin{array}{l}\text { Hypothetical monthly decline rate for } \\
\text { the first month and estimated numbers }\end{array}$} \\
\hline Months & $30 \%$ & $20 \%$ & $10 \%$ & $0 \%$ & $30 \%$ & $20 \%$ & $10 \%$ & $0 \%$ \\
\hline January & $1,272,083$ & $1,272,083$ & $\begin{array}{l}1,272,083 \\
\end{array}$ & \begin{tabular}{|l|}
$1,272,083$ \\
\end{tabular} & $1,272,083$ & \begin{tabular}{|l|}
$1,272,083$ \\
\end{tabular} & \begin{tabular}{|l|}
$1,272,083$ \\
\end{tabular} & \begin{tabular}{|l|}
$1,272,083$ \\
\end{tabular} \\
\hline February $^{\mathrm{a}}$ & 863,960 & 863,960 & 863,960 & \begin{tabular}{|r|}
863,960 \\
\end{tabular} & \begin{tabular}{|r}
863,960 \\
\end{tabular} & 863,960 & 863,960 & 863,960 \\
\hline March $^{\mathrm{a}}$ & 470,970 & 470,970 & 470,970 & 470,970 & 470,970 & 470,970 & 470,970 & 470,970 \\
\hline April $^{a}$ & 158,718 & 158,718 & 158,718 & \begin{tabular}{|l|}
158,718 \\
\end{tabular} & 158,718 & 158,718 & 158,718 & 158,718 \\
\hline May & 163,646 & \begin{tabular}{|l|}
163,646 \\
\end{tabular} & 163,646 & \begin{tabular}{|r|}
163,646 \\
\end{tabular} & 163,646 & 163,646 & 163,646 & 163,646 \\
\hline June $^{\mathrm{a}}$ & 160,282 & 160,282 & 160,282 & \begin{tabular}{|r|}
160,282 \\
\end{tabular} & 160,282 & 160,282 & 160,282 & 160,282 \\
\hline July & $1,027,721$ & $1,174,538$ & $1,321,356$ & \begin{tabular}{|l|}
$1,468,173$ \\
\end{tabular} & $1,336,037$ & \begin{tabular}{|l|}
$1,409,446$ \\
\end{tabular} & \begin{tabular}{|l|}
$1,453,491$ \\
\end{tabular} & \begin{tabular}{|l|}
$1,468,173$ \\
\end{tabular} \\
\hline August & $1,071,188$ & $1,224,214$ & $\begin{array}{l}1,377,241 \\
\end{array}$ & \begin{tabular}{|l|}
$1,530,268$ \\
\end{tabular} & $1,392,544$ & \begin{tabular}{|l|}
$1,469,057$ \\
\end{tabular} & \begin{tabular}{|l|}
$1,514,965$ \\
\end{tabular} & \begin{tabular}{|l|}
$1,530,268$ \\
\end{tabular} \\
\hline September & 972,103 & $1,110,975$ & $1,249,847$ & \begin{tabular}{|l|}
$1,388,719$ \\
\end{tabular} & $1,263,734$ & $1,333,170$ & \begin{tabular}{|l|}
$1,374,832$ \\
\end{tabular} & \begin{tabular}{|l|}
$1,388,719$ \\
\end{tabular} \\
\hline October & 942,504 & $1,077,147$ & $1,211,791$ & \begin{tabular}{|l|}
$1,346,434$ \\
\end{tabular} & $1,225,255$ & \begin{tabular}{|l|}
$1,292,577$ \\
\end{tabular} & \begin{tabular}{|l|}
$1,332,970$ \\
\end{tabular} & \begin{tabular}{|l|}
$1,346,434$ \\
\end{tabular} \\
\hline November & 896,547 & $1,024,625$ & $\begin{array}{l}1,152,703 \\
\end{array}$ & \begin{tabular}{|l|}
$1,280,781$ \\
\end{tabular} & \begin{tabular}{|l|}
$1,165,511$ \\
\end{tabular} & \begin{tabular}{|l|}
$1,229,550$ \\
\end{tabular} & \begin{tabular}{|l|}
$1,267,973$ \\
\end{tabular} & \begin{tabular}{|l|}
$1,280,781$ \\
\end{tabular} \\
\hline December & 963,947 & $1,101,654$ & $1,239,360$ & \begin{tabular}{|l|}
$1,377,067$ \\
\end{tabular} & $1,253,131$ & \begin{tabular}{|l|}
$1,321,984$ \\
\end{tabular} & \begin{tabular}{|l|}
$1,363,296$ \\
\end{tabular} & \begin{tabular}{|l|}
$1,377,067$ \\
\end{tabular} \\
\hline Total & $8,963,668$ & $9,802,813$ & $10,641,9571$ & $11,481,101$ & $\mid 10,725,871$ & $11,145,443$ & \begin{tabular}{|l|}
$11,397,187$ \\
\end{tabular} & $11,481,101$ \\
\hline (\%) & 0.56 & 0.61 & 0.66 & 0.71 & 0.67 & 0.69 & 0.71 & 0.71 \\
\hline EACR (\%) & -0.44 & -0.39 & -0.34 & -0.29 & -0.33 & -0.31 & -0.29 & -0.29 \\
\hline
\end{tabular}

EACR: Estimated Annual Change Rate

Source: Calculation results, 2020

TABLE II. The estimated number of foreign visitors and annual change rate (what if borders are closed for one month - April 2020)

\begin{tabular}{|c|c|c|c|c|c|c|c|c|}
\hline \multicolumn{5}{|c|}{ Scenario $\mathrm{A} 2^{\mathrm{b}}$} & \multicolumn{4}{|c|}{ Scenario $\mathrm{B} 2^{\mathrm{c}}$} \\
\hline \multicolumn{5}{|c|}{$\begin{array}{c}\text { Hypothetical monthly decline rate and estimated } \\
\text { numbers }\end{array}$} & \multicolumn{4}{|c|}{$\begin{array}{l}\text { Hypothetical monthly decline rate for } \\
\text { the first month and estimated numbers }\end{array}$} \\
\hline Months & $30 \%$ & $20 \%$ & $10 \%$ & $0 \%$ & $30 \%$ & $20 \%$ & $10 \%$ & $0 \%$ \\
\hline January ${ }^{\mathrm{a}}$ & $1,272,083$ & $1,272,083$ & $1,272,083$ & $1,272,083$ & $1,272,083$ & $1,272,083$ & $1,272,083$ & $1,272,083$ \\
\hline February $^{\mathrm{a}}$ & 863,960 & \begin{tabular}{|l|}
863,960 \\
\end{tabular} & 863,960 & 863,960 & 863,960 & 863,960 & 63,960 & 863,960 \\
\hline March $^{\mathrm{a}}$ & 470,970 & 470,970 & 470,970 & 470,970 & 470,970 & 470,970 & 470,970 & 470,970 \\
\hline April & 0 & 0 & 0 & 0 & 0 & 0 & 0 & \\
\hline Maya & 163,646 & 163,646 & 163,646 & 163,646 & 163,646 & 163,646 & 63,646 & 163,646 \\
\hline June $^{a}$ & 160,282 & 160,282 & 160,282 & 160,282 & 160,282 & 160,282 & 60,282 & 160,282 \\
\hline July & $1,027,721$ & $1,174,538$ & $1,321,356$ & $1,468,173$ & $1,336,037$ & $1,409,446$ & $1,453,491$ & $1,468,173$ \\
\hline August & $1,071,188$ & $1,224,214$ & $1,377,241$ & $1,530,268$ & $1,392,544$ & $1,469,057$ & $1,514,965$ & $1,530,268$ \\
\hline September & 972,103 & $1,110,975$ & $1,249,847$ & $1,388,719$ & $1,263,734$ & $1,333,170$ & $1,374,832$ & $1,388,719$ \\
\hline October & 942,504 & $1,077,147$ & $1,211,791$ & $1,346,434$ & $1,225,255$ & \begin{tabular}{|l|}
$1,292,577$ \\
\end{tabular} & $1,332,970$ & $1,346,434$ \\
\hline \begin{tabular}{|l|} 
November \\
\end{tabular} & 896,547 & $1,024,625$ & $1,152,703$ & $1,280,781$ & $1,165,511$ & $1,229,550$ & $1,267,973$ & $1,280,781$ \\
\hline December & 963,947 & $1,101,654$ & $1,239,360$ & $1,377,067$ & $1,253,131$ & $1,321,984$ & $1,363,296$ & $1,377,067$ \\
\hline Total & $8,804,950$ & $9,644,095$ & $10,483,239$ & $11,322,383$ & $10,567,153$ & $10,986,725$ & $11,238,469$ & $11,322,383$ \\
\hline (\%) & 0.55 & 0.60 & 0.65 & 0.70 & 0.66 & 0.68 & 0.70 & 0.70 \\
\hline EACR $(\%)$ & -0.45 & -0.40 & -0.35 & -0.30 & -0.34 & -0.32 & -0.30 & -0.30 \\
\hline
\end{tabular}

a. Provisional data announced by the ministry of tourism

b. Decline in demand is at the same level for each month

c. Decline in demand will recover with equal proportion month by month EACR: Estimated Annual Change Rate

Source: Calculation results, 2020

If the number of foreign tourist arrivals has reached $70 \%$ at the same rate for each month in the remainder of the year (Scenario A), the estimated rate of change is $-45 \%$ compared to 2019 due to one month's border closure, but if Scenario B becomes reality, changes in demand will be to $34 \%$ (Table II). If the number of foreign visitors decreases by $20 \%$ compared to the previous year at the same rate for each month, the demand will decrease by $40 \%$ due to one month's border closure. If Scenario B comes true, demand will fall by $32 \%$. As shown in Table II, the number of foreign tourists will decrease by $30 \%$, even if demand remains the same.

Not much different from the conditions in March, the policy to prohibit foreigners from entering Indonesia in April resulted in a decrease in the number of foreign tourists between 30\% - 45\% compared to the same month in 2019 based on the A2 and B2 scenarios. However, based on data released by [19] the number of foreign tourist arrivals in April fell drastically compared to the same month in 2019, which was $-87.54 \%$. This indicates that the COVID-19 outbreak has had a profound impact on human life in various parts of the world, not only health but also in the economic sector. The prohibition for foreigners to enter an area has reduced the number of travel by people which in turn reduces the number of foreign tourist arrivals.

Next, the estimated number of foreign visitors and the estimated annual rate of change based on the two scenarios (A3 and B3) where the Government starts to impose LargeScale Social Restrictions (PSBB) is shown in Table III. If the number of foreign visitors becomes reality at $70 \%$ as a constant for the month same year before, the rate of change will be $-46 \%$ compared to 2019 due to the two month border closure. However, if demand is to be recovered in the same proportion from the base rate, the change will be $-35 \%$. If the level of demand reaches $80 \%$ compared to the previous year, which is constant for the same month in 2019, the 
demand will decrease by $41 \%$ due to the implementation of PSBB. In the case of Scenario B, demand will decrease by $33 \%$. As can be seen in Table III, the number of tourists will decrease by $31 \%$ even if demand remains the same.

TABLE III. The estimated number of foreign visitors and annual change rate (what if borders are closed for two month, April - Mei 2020)

\begin{tabular}{|c|c|c|c|c|c|c|c|c|}
\hline \multicolumn{5}{|c|}{ Scenario $\mathrm{A} 3^{\mathrm{b}}$} & \multicolumn{4}{|c|}{ Scenario $B 3^{c}$} \\
\hline \multicolumn{5}{|c|}{$\begin{array}{c}\text { Hypothetical monthly decline rate and estimated } \\
\text { numbers }\end{array}$} & \multicolumn{4}{|c|}{$\begin{array}{l}\text { Hypothetical monthly decline rate for } \\
\text { the first month and estimated numbers }\end{array}$} \\
\hline Months & $30 \%$ & $20 \%$ & $10 \%$ & $0 \%$ & $30 \%$ & $20 \%$ & $10 \%$ & $0 \%$ \\
\hline January $^{\mathrm{a}}$ & $1,272,083$ & $1,272,083$ & $1,272,083$ & $1,272,083$ & $1,272,083$ & $1,272,083$ & $1,272,083$ & $1,272,083$ \\
\hline February $^{\mathrm{a}}$ & 863,960 & 863,960 & 863,960 & 863,960 & 863,960 & 863,960 & 863,960 & 863,960 \\
\hline $\operatorname{March}^{\mathrm{a}}$ & 470,970 & 470,970 & 470,970 & 470,970 & 470,970 & 470,970 & 470,970 & 470,970 \\
\hline April & 0 & 0 & 0 & d & 0 & 0 & 0 & \\
\hline May & 0 & 0 & 0 & 0 & 0 & 0 & 0 & \\
\hline June $^{\mathrm{a}}$ & 160,282 & 160,282 & 160,282 & 160,282 & 160,282 & 160,282 & 160,282 & 160,282 \\
\hline July & $1,027,721$ & $1,174,538$ & $1,321,356$ & $1,468,173$ & $1,336,037$ & $1,409,446$ & $1,453,491$ & $1,468,173$ \\
\hline August & $1,071,188$ & $1,224,214$ & $1,377,241$ & $1,530,268$ & $1,392,544$ & $1,469,057$ & $1,514,965$ & $1,530,268$ \\
\hline September & 972,103 & $1,110,975$ & $1,249,847$ & $1,388,719$ & $1,263,734$ & $1,333,170$ & $1,374,832$ & $1,388,719$ \\
\hline October & 942,504 & $1,077,147$ & $1,211,791$ & $1,346,434$ & $1,225,255$ & $1,292,577$ & $1,332,970$ & $1,346,434$ \\
\hline \begin{tabular}{|l|} 
November \\
\end{tabular} & 896,547 & $1,024,625$ & $1,152,703$ & $1,280,781$ & $1,165,511$ & $1,229,550$ & $1,267,973$ & $1,280,781$ \\
\hline December & 963,947 & $1,101,654$ & $1,239,360$ & $1,377,067$ & $1,253,131$ & $1,321,984$ & $1,363,296$ & $1,377,067$ \\
\hline Total & $8,641,304$ & $9,480,449$ & $10,319,593$ & $11,158,737$ & $10,403,507$ & $10,823,079$ & $11,074,823$ & $11,158,737$ \\
\hline$(\%)$ & 0.54 & 0.59 & 0.64 & 0.69 & 0.65 & 0.67 & 0.69 & 0.69 \\
\hline EACR $(\%)$ & -0.46 & -0.41 & -0.36 & -0.31 & -0.35 & -0.33 & -0.31 & -0.31 \\
\hline
\end{tabular}

a. Provisional data announced by the ministry of tourism

b. Decline in demand is at the same level for each month

c. Decline in demand will recover with equal proportion month by month EACR: Estimated Annual Change Rate

Source: Calculation results, 2020

Furthermore, if the government policy is extended until September 2020 with two scenarios, the estimated number of foreign tourists visiting is shown in Table IV. If the number of foreign visitors is $70 \%$ at the same rate for each month of the remainder of the year, the estimated rate of change is $-66 \%$ compared to 2019 due to the five-month border closure, but if Scenario B becomes reality, changes in demand will be $-61 \%$. If the demand rate is $80 \%$ over the previous year, at the same rate for each month, the demand will fall by $64 \%$ due to the closure of the five-month border. If Scenario B comes true, demand will drop by $60 \%$. The number of tourists will decrease by $59 \%$, even if demand remains the same as shown in Table IV.

TABLE IV. The estimated number of foreign visitors and annual change rate (what if borders are closed for six month, April - September 2020)

\begin{tabular}{|l|r|r|r|r|r|r|r|}
\hline \multicolumn{5}{|c|}{ Scenario A4 ${ }^{\text {b }}$} & \multicolumn{5}{c|}{ Scenario B4 $^{\text {c }}$} \\
\hline \multicolumn{3}{|c|}{ Hypothetical monthly decline rate and estimated } \\
numbers
\end{tabular}

EACR: Estimated Annual Change Rate

Source: Calculation results, 2020

According to the estimation results of alternative scenarios (scenario A and scenario B) until September 2020, the decline in demand is expected to be in the range of $29 \%$ to $66 \%$. This means, if the worst case scenario comes true, it will be one of the worst tourism crises Indonesia is experiencing. These results suggest that COVID-19 is more effective than other health outbreaks such as SARS [8] [20], Avian Flu [21], and Swine Flu [10] observed in the last two decades.

\section{CONCLUSION}

The final report of this research was made at the end of September 2020. The estimated reduction in the number of foreign tourists visiting with the PSBB policy until the end of September 2020 is $59 \%$ compared to 2019 in the same month. The latest news on COVID-19 shows that the future of the pandemic is still unclear. On the other hand, we must also have an optimistic outlook. To minimize the danger of the COVID-19 pandemic to Indonesian tourism, it is necessary to develop a recovery plan and implement it immediately. In this case, the research findings must be considered in a hypothetical scenario. On the other hand, providing information and highlighting stakeholders for future planning and decisions makes this study important.

\section{ACKNOWLEDGMENT}

THANKS FOR COMMENTS AND SUGGESTIONS FROM REVIEWERS AND AUDIENCES OF THE 3RD INTERNATIONAL CONFERENCE ON BANKING, ACCOUNTING, MANAGEMENT, AND ECONOMICS (ICOBAME) 2020.

\section{REFERENCES}

[1] Ministry of Tourism and Creative Economy of Indonesia, "Foreign Tourist Visit Data". Retrieved from http://www.kemenparekraf.go.id/post/data-kunjungan-wisatawanmancanegara-bulanan-tahun-2020, May 4, 2020.

[2] B. Mckercher and K. Chon, "The over-reaction to SARS and the collapse of Asian tourism”. Annals of Tourism Research, 31 (3): 716719, 2004.

[3] J.C. Henderson, "Managing a health-related crisis: SARS in Singapore". Journal of Vacation Marketing, 10 (1): 67-77. https://doi.org/10.1177/135676670301000107, 2004.

[4] R. Pine and B. McKercher, "The impact of SARS on Hong Kong's tourism industry". International Journal of Contemporary Hospitality $\begin{array}{llll}\text { Management, } & 16 & \text { (2), } & \text { pp. }\end{array}$ https://doi.org/10.1108/09596110410520034, 2004.

[5] H.I. Kuo, C.C.Chen, W.C.Tseng, L.F. Ju, , B.W. Huang, “Assessing impacts of SARS and Avian Flu on international tourism demand to Asia”. Tourism Management, 29 (5): 917-928, 2008.

[6] A.K.M. Au, B. Ramasamy and M.C.H.Yeung, "The effects of SARS on the Hong Kong tourism industry: An empirical evaluation. Asia Pacific". Journal of Tourism Research, 10 (1): 85-95. DOI: 10.1080/1094166042000330236, 2005.

[7] J.C. Henderson, and A. Ng, "Responding to Crisis: Severe Acute Respiratory Syndrome (SARS) and Hotels in Singapore". International Journal of Tourism Research, 6: 411-419, 2004.

[8] G. Wall, Recovering from SARS: The case of Toronto Tourism. In Tourism, Security and Safety: From Theory to Practice (Eds. Mansfeld, Y. and Pizam, A.) 143-152. Oxford: Elsevier ButterworthHeinemann, 2006

[9] S. Page, H. Song and D.C. Wu, "Assessing the Impacts of the Global Economic Crisis and Swine Flu on Inbound Tourism Demand in the United Kingdom". Journal of Travel Research, 51(2): 142-153. https://doi.org/10.1177/0047287511400754, 2012. 
[10] T.H. Haque, and M.O. Haque, "The swine flu and its impacts on tourism in Brunei". Journal of Hospitality and Tourism Management, 36, pp. 92-101, https://doi.org/10.1016/j.jhtm.2016.12.003, 2018.

[11] M. Novelli, L.G. Burgess, A. Jones and N.W. Ritchie, 'No Ebola...still doomed' - The Ebola-induced tourism crisis. Annuals of $\begin{array}{llll}\text { Tourism } & \text { Research, } & 70, & \text { pp. }\end{array}$ https://doi.org/10.1016/j.annals.2018.03.006, 2018.

[12] Isaac Mizrachi and Galia Fuchs, "Should we cancel? An examination of risk handling in travel social media before visiting ebola-free destinations". Journal of Hospitality and Tourism Management, Volume 28, 2016, Pages 59-65, https://doi.org/10.1016/j.jhtm.2016.01.009, 2016.

[13] B. K. Hassani, Scenario Analysis in Risk Management. Switzerland: Springer Int. Publishing, 2016.

[14] C.A. de Kluvyer, Bottom-Up Sales Forecasting Through Scenario Analysis, Industrial Marketing Management, (9): 167-170, 1980.

[15] UNWTO, "International Tourist Arrivals Could Fall by 20-30\% in 2020." Retrieved from https://webunwto.s3.eu-west1.amazonaws.com/s3fs-public/2020-03/24-03Coronavirus_0.pdf. 2020, March 27.

[16] M. E. Horuz, Turizmciler Kovid-19 salgını sonrası dönemden umutlu, Anadolu Ajans1, Retrieved from https://www.aa.com.tr/tr/ekonomi/turizmciler-kovid-19-salginisonrasidonemden-umutlu-/1787487 on April 1, 2020.

[17] Fatih Günay, Engin Bayraktaroğlu, Kahraman Özkul, “Assessing the Short-term Impacts of COVID-19 Pandemic on Foreign Visitor's Demand for Turkey: A Scenario Analysis". Journal of Ekonomi 04 (2020) 80-85, 2020.

[18] Republic of Indonesia, Peraturan Menteri Hukum dan Hak Asasi Manusia RI Nomor 11 Tahun 2020 tentang Pelarangan Sementara Orang Asing Masuk Wilayah Republik Indonesia yang berlaku sejak tanggal April 2, 2020.

[19] Ministry of Tourism and Creative Economy of Indonesia, Statistik Wisatawan Nusantara 2020. Retrieved from http://www.kemenparekraf.go.id/post/statistik-profil-wisatawannusantara-2020.

[20] M. McAleer, B.W. Huang, H.I. Kuo, C.C. Chen, C.L. Chang, “An econometric analysis of SARS and Avian Flu on international tourist arrivals to Asia". Environmental Modelling \& Software, 25 (1): 100 106. https://doi.org/10.1016/j.envsoft.2009.07.015, 2010.

[21] Milan Brahmbhatt, "Avian Influenza: Economic and Social Impacts." The World Bank, Washington, D.C., a speech delivered September 23, 2005. 